\title{
Mobile Banking Operations and Banking Facilities to Rural People in Bangladesh
}

\author{
K. M. Anwarul Islam ${ }^{1}$, Umme Salma ${ }^{2}$ \\ ${ }^{1}$ Department of Business Administration, The Millennium University, Dhaka, Bangladesh \\ ${ }^{2}$ Department of Computer Science and Engineering, Bangladesh University, Dhaka, Bangladesh \\ Email address: \\ ai419bankingdu@gmail.com (K. M. A. Islam), ummesalma.cse@gmail.com (U. Salma)
}

\section{To cite this article:}

K. M. AnwarulIslam, Umme Salma. Mobile Banking Operations and Banking Facilities to Rural People in Bangladesh. International Journal of Finance and Banking Research. Vol. 4, No. 4, 2016, pp. 147-162. doi: 10.11648/j.ijfbr.20160204.14

Received: January 23, 2016; Accepted: May 17, 2016; Published: August 4, 2016

\begin{abstract}
Mobile financial service is an approach to offering banking system which enables users to perform banking transaction. It is easy and cost effective for mobile transaction. In Bangladesh, several banks are providing their banking service via mobile technology which is very much effective for customers. This research paper examines the Mobile banking system of commercial banks, technology that are using mobile bank and factors of influences the uses of mobile bank. In Bangladesh perspective identify problems and challenges how does the user in risk with regards to mobile Banking and the benefits of users. Data were collected through observation of banking services related to mobile technology, and interviewed clients, agents and bank officials. The results revealed that mobile banking system are easy for modern banking system. The mobile banking that does can be handled all over in remote area within a single moment. Mobile banking through an SMS based service would require the lowest amount of effort, in terms of cost and time. Mobile Application based banking is poised to be a big m-commerce feature in Bangladesh and it could well be the driving factor to increase sales of high-end mobile phones.
\end{abstract}

Keywords: M-banking, SMS Banking, bKash, Rural People, DBBL, IBBL

\section{Introduction}

\subsection{Background of the Research}

The rapid growth of information technology, especially in mobile devices have created opportunities for new and innovative mobile banking services. Along with the widely used short messaging system (SMS) for communication, the sophistication of mobile phone function has affected the banking industry globally. The mobile phone technology advancement also prompted banking industries to introduce mobile banking services. Rapid growth of mobile banking enabled people to settle their banking transactions easily while saving time as every step of the procedure was at their fingertips. Mobile banking (also known as M-Banking or SMS Banking) is defined as a form of banking transaction via a mobile phone. Mobile banking allows customers to check their account balances, transfer funds, reload on phone airtime, perform cash in and cash out transactions as well as receive information alerts on the latest transactions in their accounts. All this can be done through mobile phone devices for example, Personal Digital Assistant (PDA), Smartphone or the regular basic mobile phone.

Mobile phones have become a tool for everyday use, which creates an opportunity for the evolution of banking services to reach the previously unbanked population through mobile banking. The use of mobile banking can make basic financial services more accessible to low-income people, minimizing time and distance to the nearest retail bank branches. The outstanding growth of mobile sector worldwide has created a unique opportunity to provide social and financial services over the mobile network. With over 4 billion mobile cellular subscriptions worldwide, mobile network has the ability to immediately offer mobile banking to $61 \%$ of the world population. But still the usage of mobile banking is a debatable issue among the educated persons and professional body because of the risk involved in such transactions.

Bangladesh Bank defines the Mobile financial Services as -"Mobile Financial Services (MFS) is an approach to 
offering financial services that combines banking with mobile wireless networks which enables for user to execute banking transactions. This means the ability to make deposits, withdraw, and to send or receive funds from a mobile account. Often these services are enabled by the use of bank agents that allow mobile account holders to transact an independent agent location outside of bank branches. MFS is still new in Bangladesh and this paper aims to capture its early development and learn lessons.

- To study the technical and business model of mobile banking in Bangladesh.

- To identify prospect of mobile banking in Bangladesh.

- To detect problems of mobile banking in Bangladesh.

- To compare services through mobile banking of different banks.

- To make suggestions on the basis of findings.

\subsection{Overview of Mobile Banking}

Mobile banking (also known as M-Banking, m-banking, SMS Banking) is a term used for performing balance checks, account transactions, payments, credit applications and other banking transactions through a mobile device such as a mobile phone or Personal Digital Assistant (PDA). The earliest mobile banking services were offered over SMS. With the introduction of the first primitive smart phones with WAP support enabling the use of the mobile web in 1999, the first European banks started to offer mobile banking on this platform to their customers.

There are 160 million people in Bangladesh at the time, of which, $87 \%$ didn't have a bank account and most are living in rural areas. This represented a huge untapped market for commercial banks. However, establishing bank branches across rural Bangladesh is not an option because of the costs and of regulatory constraints as the central bank only grants new branch opening licenses for a maximum of 15 branches in a year. According to market research conducted by Dutch-
Bangla Bank Limited (DBBL) before it started its mobile banking initiative, just 13 percent of the 160 million people in Bangladesh had bank accounts. Yet within the unbanked 87 percent, which is more than 139 million people, 50 percent have mobile phones. Mobile operator agents are widely distributed, the devices themselves are affordable and service coverage is constantly expanding. Similar numbers are common in developing nations all over the world for the same reasons, which is why the opportunity for banks to bring basic financial services to the unbanked via the mobile channel is so big. In mid-2011, DBBL launched a solution for customers to manage money with their mobile phones, depositing and withdrawing funds as well as conducting other financial transactions. In addition to making banking more convenient and accessible for customers, the mobile channel provides a low-cost methodology for DBBL. "BRAC Bank Limited" is introduced mobile banking that is enabled millions of banked and unbanked people to deposit, withdraw and transfer money through mobile phones. bKash, a joint venture between BRAC Bank and US-based money in Motion, will provide mobile banking with a fully encrypted VISA technology platform for transactions through mobile phones. Any mobile user can register and open up a bKash account and then do transactions through their mobile phones in easy, convenient and reliable way.

Study on mobile banking for Bangladesh consumer conducted by. Technology has been increasingly employed in customer service quality and deliveries, reduces costs, and standardizes core service offerings. One of the first commercial applications of the mobile commerce was mobile banking (m-banking). Mobile Banking has been gaining increasing popularity amongst various sections of the society for past few years.

\subsection{Charge Comparison Table of Different Mobile Banking in Bangladesh}

Table 1. Charge Comparison about m-banking.

\begin{tabular}{|c|c|c|c|c|c|}
\hline Service Type & DBBL & bKash & \multicolumn{3}{|l|}{ IBBL } \\
\hline Registration Fee & Free & Free & \multicolumn{3}{|c|}{$\begin{array}{l}\text { Free For Customer. } \\
\text { Agent will get acom mission fromIBBL@5Tk.PerAccount Opened }\end{array}$} \\
\hline Cash-in & $\begin{array}{l}1 \% \text { of the transaction } \\
\text { amount or } 5 / \text {-which hever } \\
\text { is higher }\end{array}$ & Free & $\begin{array}{l}\text { Free for cus } \\
\text { Agent will } \\
\text { From (Tk) } \\
50 \\
1001 \\
5001 \\
10001 \\
15001\end{array}$ & $\begin{array}{l}\text { er } \\
\text { ommission fi } \\
\text { To (Tk) } \\
1000 \\
5000 \\
10000 \\
15000 \\
\text { Upto25000 }\end{array}$ & $\begin{array}{l}\text { IS action slabs given below: } \\
\text { Charges (Tk) } \\
1.00 \\
2.00 \\
4.00 \\
8.00 \\
10.00\end{array}$ \\
\hline Cash-out & $\begin{array}{l}2 \% \text { of the transaction } \\
\text { amount or Tk.10/-which } \\
\text { hever is hig her }\end{array}$ & PerTransaction $1.85 \%$ & $\begin{array}{l}\text { Customer b } \\
\text { From (Tk) } \\
50 \\
151 \\
501 \\
1001 \\
10000\end{array}$ & $\begin{array}{l}\text { W charges } \\
\text { To (Tk) } \\
150 \\
500 \\
1000 \\
10000 \\
\text { Upto25000 }\end{array}$ & $\begin{array}{l}\text { Charges }(\mathrm{Tk}) \\
4.00 \\
8.00 \\
12.00 \\
@ 10.0 \text { /thousand } \\
1 \% \text { oftheamount }\end{array}$ \\
\hline Fund Transfer & Free & Tk.2.00/Transaction & \multirow{2}{*}{\multicolumn{3}{|c|}{$\begin{array}{l}\text { Tk.2.00/Transaction } \\
\text { Free for Customer. Merc hant willpay } 0.5 \% \text { or Tk.5 which hever is hig } \\
\text { hercom mission }\end{array}$}} \\
\hline Payment & Free & Free & & & \\
\hline Balance Check & Tk2.00/- & Free & \multicolumn{3}{|l|}{ Free } \\
\hline
\end{tabular}




\begin{tabular}{|c|c|c|c|}
\hline Service Type & DBBL & bKash & IBBL \\
\hline Mobile Top-up & Free & Free & Free for customer. Telecom will provide commission as per agreements \\
\hline Salary Disbursement & Free & Not mentioned & $\begin{array}{l}\text { Free for customer. Corporate house will provide commission as per } \\
\text { agreement }\end{array}$ \\
\hline $\begin{array}{l}\text { Allowance } \\
\text { Disbursement }\end{array}$ & Free & Not mentioned & Free for customer. Govt may provide commission as per rate \\
\hline $\begin{array}{l}\text { Remittance } \\
\text { Disbursement }\end{array}$ & Free & Not mentioned & Free for customer. IBBL will provide the Telecom/agent charge \\
\hline
\end{tabular}

\subsection{Problem Statement}

Regardless to the facts that there has been a lot of research papers conducted on the topic of Mobile banking abroad, unfortunately only few studies were carried out in Bangladesh. This is probably due to the fact that Mobile banking is to some extent new in Bangladesh. Therefore, the lack of information on this topic resulted in insufficient knowledge and literature on the key determinants in Mobile banking adoption within Bangladesh. Evidences and conclusions that have been conducted abroad can be some houseful but it might not be consistent and accurate in the perspective of mobile banking in Bangladesh. Due to the reasons listed above, more research on this topic should be covered to validate whether the results from these studies would be reliable to Bangladesh

This paper attempted to assist improvement of mobile banking services through investigating the customer adoption. In addition, this paper discovered the relationship between several variables such as perceived usefulness, perceived ease of use, compatibility, perceived self-efficacy, subjective norms, perceived credibility, perceived risk and user predisposition, and the adoption of mobile banking. Models such as TAM and Extended TAM were used and adopted to help classify the variables that will Influence users' intention to adopt mobile banking.

\subsection{Research Questions}

The study seeks to investigate the influencing factors and case study of mobile banking in Bangladesh.

Question 1: What are the enabling technologies for mobile banking using a cell phone?

Question 2: Overview and Case study of mobile banking in Bangladesh?

Question 3: What are the main factors influencing the usages of mobile banking by the mobile banking participants?

Question 4: What influences the users to trust mobile banking?

Question 5: How does the user in Bangladesh perceive risk with regards to mobile Banking?

Question 6: What is the perception of mobile banking users in Bangladesh about the convenience in using mobile banking?

Question 7: What comparative advantages do the mobile banking users enjoy?

Question 8: What are the opportunities and challenges in mobile banking?

\subsection{Research Objectives}

- To examine the factors that influences the intention to use of mobile banking services in Bangladesh.

- To examine the opportunities and challenges in mobile banking.

- To evaluate mobile banking service in terms of its adoptability.

\subsection{Significance of Research}

Since the topic of Mobile Banking is relatively new in Bangladesh, there are a lot of gaps which needs to be covered. This paper work is an addition to the limited number of current literatures on the topic of Mobile Banking in Bangladesh. A theoretical model was presented and also was implemented in order to classify the key determinants of users 'adoption of Mobile Banking. The central aim of this paper was to identify the determinants of Mobile Banking adoption among the citizens in Bangladesh and also aims to fill the gaps between previous researches that were conducted in Bangladesh. This research can be handy for several parties. Since there are insufficient previous paper works regarding the factors that influence the adoption of Mobile Banking in Bangladesh, future researchers can use this study as a reference to their work. Governing bodies can also use this study in order to stimulate the growth of Mobile Banking. By identifying the factors or determinants, the governing bodies will then have the advantage of a transparent picture on the scenario Mobile Banking adoption in Bangladesh.

\subsection{Scope of the Research}

The scope of this research includes Different Mobile Bank overview and business process and services for their subscriber in Bangladesh. The group that will be focused on will be the mobile subscribers, age between 20 -50.The scope also included examining the factors that influence the users' choice whether or not to adapt the usage of Mobile banking in their daily lives. The study also took a glance on various definitions of mobile banking and its history and future in Bangladesh

\subsection{Limitation of Mobile Banking}

- Mobile Banking offers non checking limited purpose account only.

- Most people have not enough idea about mobile banking yet.

- The customer who has already an account with the bank, he needs addition account for mobile banking. 
- The customer who has the convention and mobile bank account both, he cannot access the conventional account through mobile account.

- Mobile banking is being used for fund transfer mainly. Customer does not keep deposit for long duration.

- Mobile banking has no various deposit schemes as of conventional banking yet.

- Mobile banking has no investment/loan schemes yet.

- The data is transferring through a third party cellular network, so there is a security threat.

- Mobile bank has not interbank fund transfer facility yet

\subsection{Sources of Data}

Both primary and secondary sources were used for the research purpose. Secondary data were used for providing the theoretical background to the research problem. The secondary data sources were-journal, books, internet etc. Primary data was collected through mobile banking user, agent and bank survey by using appropriate research instrument. In the primary data collection procedure every individual respondent has been considered as potential respondent in the research.

\section{Literature Review}

\subsection{Introduction}

Financial service is experiencing a period of unprecedented change- new entrants, new product, downsizing, mergers and acquisitions, in addition to the new delivery channel: the internet (Birch and Young, 1997). Despite all the millions of dollars that have been spent on building internet banking system, studies and research have indicated that potential users may not use the system in spite of their availability. These points out the need for further research to identify the factors that determine the acceptance of Internet banking by the users. In this chapter, previous researches that have been conducted about mobile banking will be analyzed and discussed. Various definitions and opposing definitions will be discussed thoroughly. In addition, the background information about mobile banking will be discussed in this chapter. Besides that, various reasons why consumers choose to adopt mobile banking will be discussed. The position of mobile banking in other countries plus Bangladesh will also be looked at in this chapter. Moreover, the essential factors that influence mobile banking acceptance will also be talked about

\subsection{Mobile Financial Service}

The rapid growth of mobile phone users and countrywide coverage of mobile operator's network has made their delivery channel an important tool-of-the-trade for extending banking services to the unbanked/banked population, especially to expedite faster delivery of remittances across the country. From legal and regulatory perspective, only the bank-led model is allowed to operate in Bangladesh.

Approved Mobile Financial Services (in broad categories) are listed below -

- Disbursement of inward foreign remittances.

- Cash in /out using mobile account through agents/Bank branches/ ATMs /Mobile Operator's outlets.

- Person to Business Payments - e.g. a. utility bill payments, b. merchant payments.

- Business to Person Payments e.g. salary disbursement, dividend and refund warrant payments, vendor payments, etc.

- Government to Person Payments e.g. elderly allowances. Freedom-fighter allowances, subsidies, etc.

- Person to Government Payments e.g. tax, levy payments.

- Person to Person Payments (One registered mobile Account to another registered mobile account).

- Other payments like microfinance, overdrawn facility, insurance premium, DPS, etc

Bangladesh Bank has fixed the transaction limit for the account holders of mobile financial services at maximum Tk. 10,000 daily and a total of Tk. 25,000 on monthly basis vide DCMPS Circular No. - 10/2011 December 14, 2011. A holistic view of the MFS status as of March 2014 are given in the table below (as Bangladesh bank database) -

Table 2. Mobile Financial Service Data.

\begin{tabular}{ll}
\hline No. of Banks permitted & 28 \\
Started MFS Operation & 19 \\
Registered Customers & 15.02 million \\
Agents & $2,93,143$ \\
Transactions (billion Taka) & 78.49 billion \\
\hline
\end{tabular}

\subsection{Mobile Banking System Model}

Mobile banking is seen to be an extension of the existing payment infrastructure of a bank to mobile phones as a channel for the leveraging of the mobile network and its reach, to deliver banking services to consumers. The mobile banking infrastructure thus sits in a similar technical environment to the banks ATMs, POS, branch and internet banking service offerings. A bank's core banking system, the system that houses the consumer's account and related transaction management and history, would require a means to translate banking instructions, received from consumers, through one of the bank channels such as ATMs or the internet, into a format that the core banking system can process. This translation is normally performed by an EFT channel switch. The EFT channel switch would switch transactions from the channel to the appropriate area within the core banking system. 


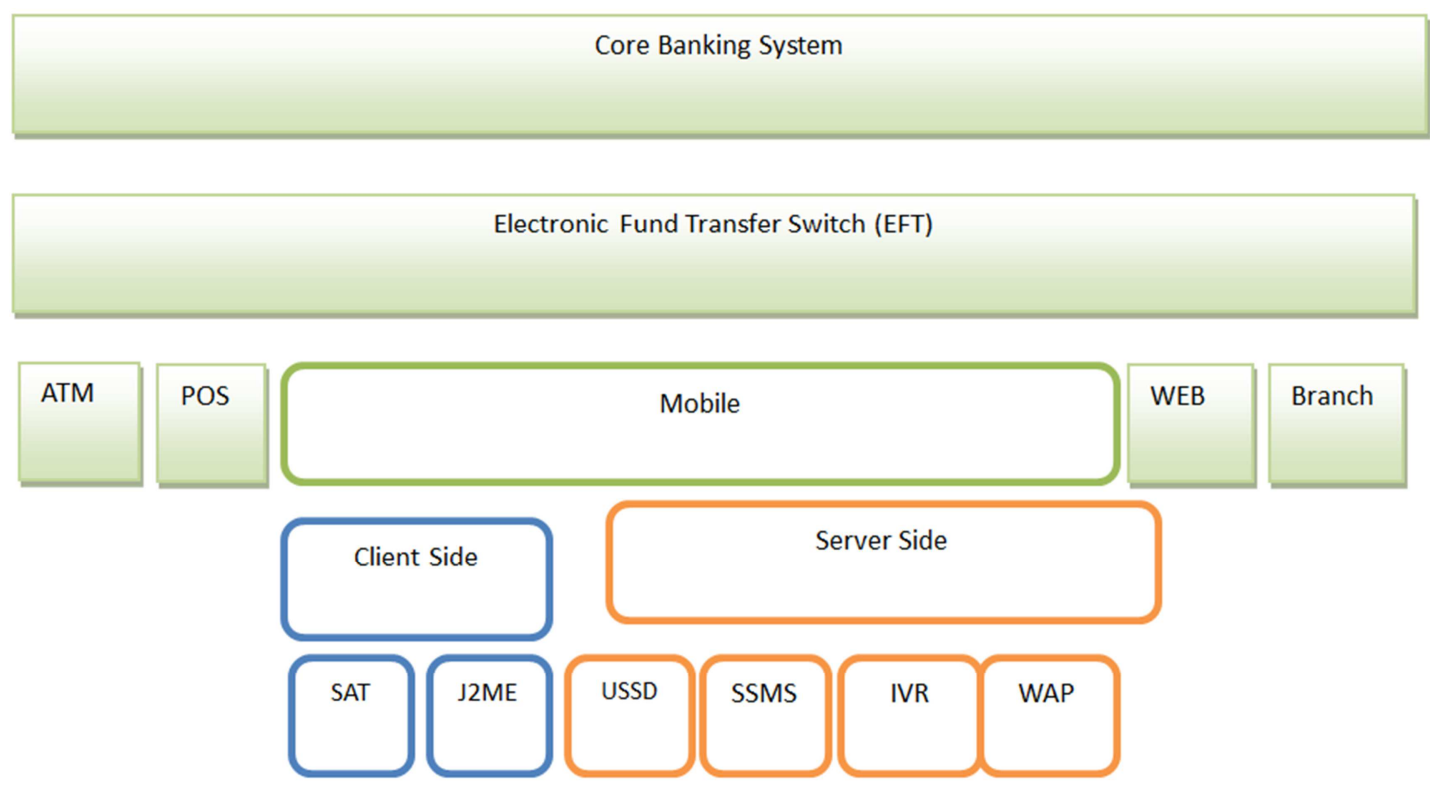

Figure 1. Mobile banking system \& overall banking architecture.

\subsubsection{Mobile Banking Bearer Technology}

This section addresses the front-end component or consumer-facing mobile banking technologies. This component of the end-to-end mobile banking value chain is typically supplied or customized by either a mobile banking vendor or the specialized technology unit within a bank. These Mobile Banking Technologies can be categorized into two environments:

Server-Side Technologies

Server-side technologies are those applications built on a server, away from the consumer's SIM or Mobile handset. Examples of server-side technologies would be SMS, IVR, USSD2 and WAP.

Client-Side Technologies

Client-side technologies are those applications, solutions and service offerings built or Embedded on a consumer SIM or mobile handset. Examples of client-side applications are S@T and J2ME (JAVA).

These consumer-facing technologies each have differing characteristics and processes. Each of these technologies requires that the consumer register or activate the application with the bank/MNO/vendor offering the service in the market.

This registration process is defined by the service provider and serves as an initial identification of the consumer to ensure ongoing trust in, and security of, the transaction. There are numerous methods of registering or activating customers in existence, all of which require the endorsement of the bank offering the service.

Consumer registration often creates a barrier to consumer adoption, but serves as a necessary step in the process of eliminating fraud and potential transactional risk in the offering (as well as being a regulatory requirement).

In server-side applications, consumer data that enables the processing of transactions, such as account/card details, are typically stored in a secured environment, on a server at a bank or at their allocated service provider/vendor.

\subsubsection{Evolution of Mobile Technology}

The first radio telephone was discovered in US at the late 1940s and the main reason behind that was to connect mobile users in vehicles to the public network. In the1960s, a new system called Improved Mobile Telephone Service (IMTS) was initiated by Bell system (Take, 2010). For an easier and more adequate explanation of mobile technology, the innovation has been simplified and categorized into 4 groups of generations. Each one of these generations is an advancement or improvement of the previous generation. These generations are categorized as, first generation (1G), second-generation $(2 \mathrm{G})$ and $(2.5 \mathrm{G})$, third generation $(3 \mathrm{G})$, and finally the fourth generation $(4 \mathrm{G})$.

Ashiho (2003) stated that the first generation of mobile technology or $1 \mathrm{G}$ had only voice facility as the main feature and that the mobile phones were based on the analogue system. During the 1970 s, $1 \mathrm{G}$ analog system for mobile communications saw two significant developments: the invention of the microprocessor and digitization of the control link between the mobile phone and the cell site (S. Take, 2010). In addition to that, the semi-conductor technology and microprocessors made mobile systems smaller, lighter, and more sophisticated a reality. The well known among first generation systems were advanced mobile phone system (AMPS), Nordic mobile telephone (NMT), and total access communication system (TACS). Besides that, since the introduction of 1 Gphones to the world, the mobile market experienced an annual growth rate of 30 to 50per cent, subscribers rising to nearly 20 million by 1990 (Ashiho, 2003)

In Europe in the early 1990s, 2G phones using global system for mobile communications (GSM) were used. Ashiho (2003) mentioned that the motivation behind developing $2 \mathrm{G}$ cellular systems was the need to improve transmission quality, system capacity, and coverage. Take (2010) stated that - the new system (2G) provided better quality and higher capacity at lower cost to customers\|. GSM 
was also the first commercially operated digital cellular system which is based on TDMA (Take, 2010).GSM was also considered as the most successful family of cellular standards, which includes GSM900, GSM-railway or (GSM-R), GSM1800 (Ashiho, 2010). The GSM has also the ability to operate as dual-band or tri-band phones, as they are adaptable to the local frequency system in the region the user travels through. (The Mobile Phone Directory. 2009). Just like 1G, the main transmission that controls the airways is speech transmission, but it has been mentioned that the demand for fax, short message, and data transmission is growing rapidly (Ashiho, 2003).

\subsubsection{Unstructured Supplementary Service Data (USSD)}

In its simplest definition, USSD is a menu driven form of SMS where a customer would receive a text menu on their phone as opposed to a string of words. USSD is a data bearer channel in the GSM network. Like SMS, it transports small messages of up to 160 characters between the mobile handset and the network. Unlike SMS, which is 'store and forward', USSD is session based and can provide an interactive dialog between the user and a certain set of applications. In other words, both sides of the dialogue happen during a session whereas an SMS based interaction is broken into each segment of communication between the client and the service.

USSD1 only allows one way communication to the network, USSD2 allows two way communications between the user and the network. WithUSSD1, the interaction between the user and the service would be broken into each communication segment, much like SMS. With

USSD2 it would be held in the same session and allow for a flowing conversation between the user and the service. This is similar to e-mail and instant messaging, e-mail waits for the recipient to read and respond while as instant messaging allows for immediate dialogue. USSD is as standard a feature as SMS and is available in an estimated $95 \%$ of handsets today. USSD requires no pre-configuration on the consumers SIM or handset and is already built into most GSM networks. MNOs do, however, need to commercialize the product by establishing the necessary bearer channel billing capability, and promoting the use of USSD for value added services in addition to internal network and customer care use. e.g. from
*100\# which would deliver an SMS balance of your prepaid airtime account to a more intuitive full service menu as Discussed below.

A registered consumer would dial a number that includes *s and \#s. This number could be saved in the consumer's phone book as the bank's name to avoid confusion in dialing or having to remember the USSD string.

\subsection{Research Related on the Variables}

\subsubsection{Technology Acceptance Model (TAM) and Extended TAM}

The technology acceptance model is an influential extension of Ajzen and Fishbein's theory of reasoned action (TRA). It was introduced and developed by Fred Davis in 1986 (Davis et al., 1989). TAM is a model obtained from a theory that addresses the issue of how users come to accept and use a technology. The model proposes that when users are presented to a new software package, a number of variables persuade their decisions about how and when they will use it. Snow et al., (2006) added that the role of TAM is not only to gain knowledge of how technology is issued within organizations, but also how practitioners can influence the development process to positively affect the reception and hence the acceptance of new technologies in a business environment. There are two specific variables, perceived usefulness and perceived ease of use, which are assumed to be fundamental factors of user acceptance (Davis and Arbor, 1989). Bhatti (2007) stated that the TAM's basic construct doesn't fully reflect the precise influences of technological and usage context factors that might differ the user's acceptance. Matheson et al., (2001) argued that the TAM is limited due to the lack of barriers that controls the individual from using an Information Technology if they choose too. Moreover, researchers have also mentioned that due to the generality of TAM, it fails to provide more significant data on user's opinions and requires integration with other IT acceptance models to improve its explanatory and specificity (Mathieson, 1991; Agarwal and Prasad, 1998) Davis, F. D. (1989). Perceived Usefulness, Perceived Ease of Use, and User Acceptance of Information Technology, MIS Quarterly, 13(3), 31-340.

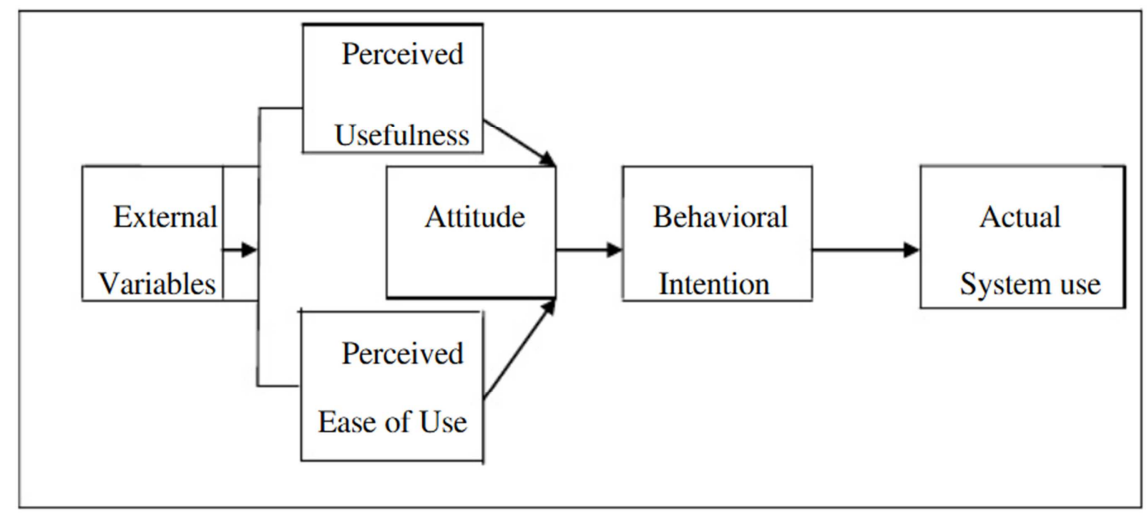

Figure 2. Technology Acceptance Model. 


\subsubsection{Extended Technology Acceptance Model}

Consequently these two determinants may not fully explain the factors which expect the acceptance of a technology application such as mobile banking. Previous studies have extended the original TAM by adding some constructs into the original TAM model to facilitate understanding of the intention to use mobile banking in Bangladesh. Luarn and Lin (2004) amended the original TAM by adding perceived credibility which was also defined by Wang et al., (2003), perceived self-efficacy which was supported by several previous studies (Agrawal et al., 2000; Chau, 2001; Hong et al., 2001; Johnson \& Marakas, 2000)

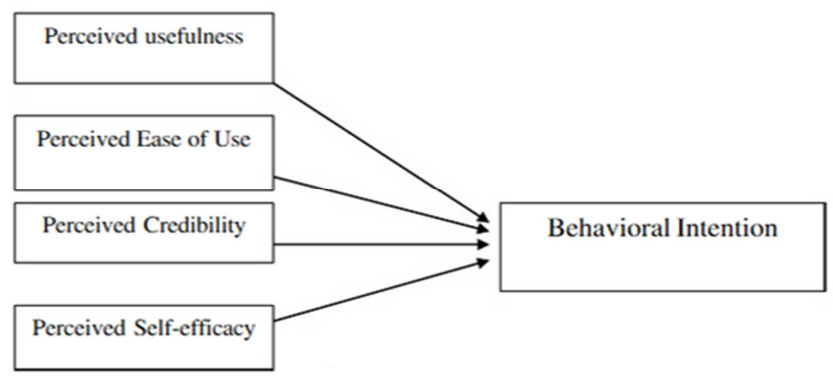

Figure 3. ETA Model.

\section{Research Methodology}

\subsection{Introduction}

The objective of this research is to identify the key determinants of Mobile Banking adoption among users in Bangladesh. Therefore, this chapter provides description of the methodology used for this research. In this study, there is a detailed indication on the instruments used in the data mining process. Both the conceptual framework and the theoretical framework are presented in this chapter. There is also enlightenment on how the independent variables will influence the independent variables and the suggested hypotheses. Additionally, the questionnaire design, research approach, data resources, data collection method, measurement of the variables, sampling method, sample size/population size, unit of analysis and data analysis techniques will also be elaborately explained in this research.

\subsection{Conceptual Framework}

In order to build a conceptual framework, various factors have been taken into consideration as potential variables. After extensive studies done abroad, six variables have been identified as possible key factors of Mobile Banking adoption in Bangladesh. Perceived usefulness is seen as a determinant of consumer's intention to adopt mobile banking. Another predicted determinant is perceived ease of use. Perceived innovativeness is predicted to have an effect on the perceived ease of use. Both perceived usefulness and perceived ease of use were adopted from the TAM model. Another estimated determinant of consumers' intention to use mobile banking is perceived credibility. Additionally, subjective norm is also seen as a possible determinant that would persuade consumer adoption. Another possible determinant that would influence the adoption of mobile banking and was discussed in this chapter is Perceived risk. Finally, the last possible determinant is user predisposition, which might be influencing the adoption of mobile banking in Bangladesh.

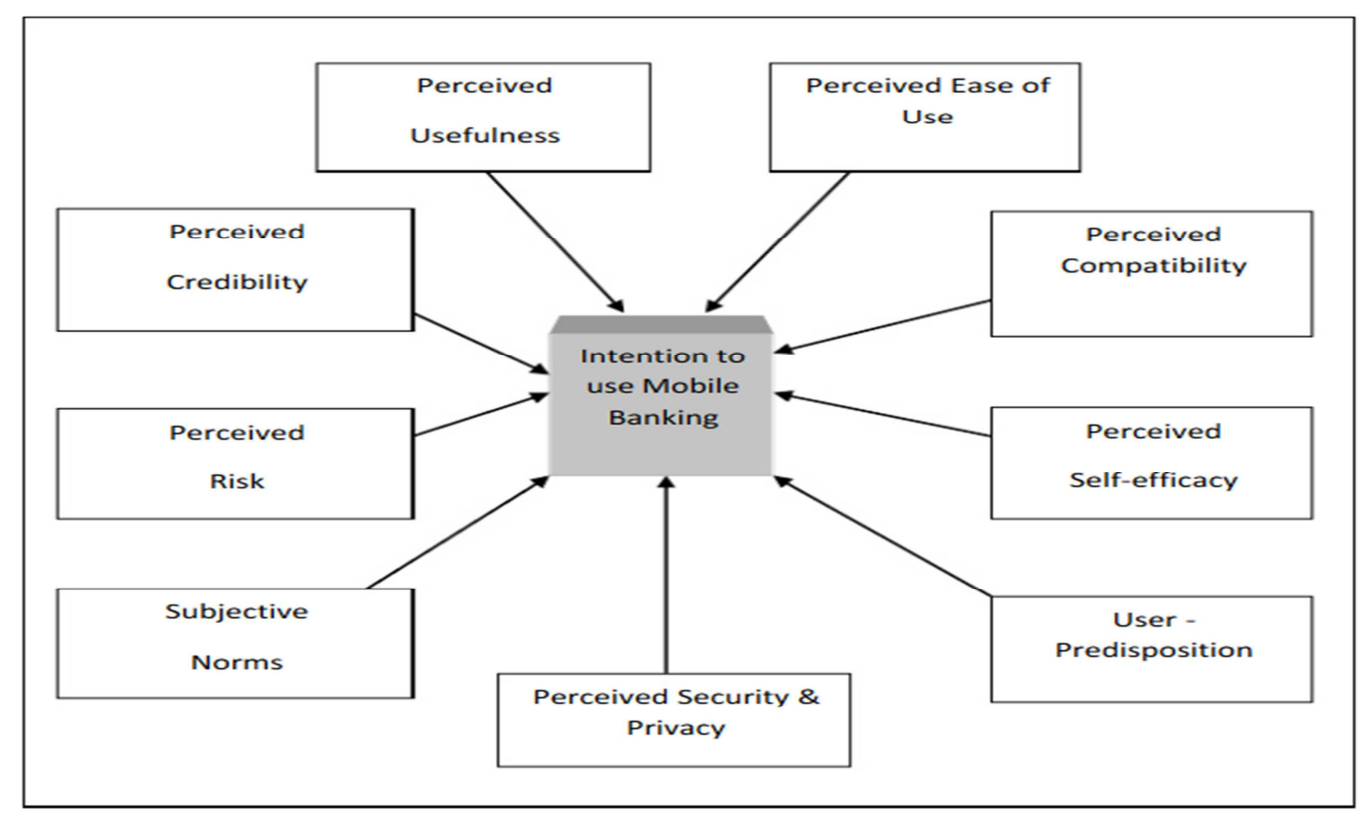

Figure 4. Theoretical Framework.

TAM model has been adopted and additional appropriate constructs have been added. This section explains in details the 
justification for the constructs to be integrated in the research and the hypothesized affiliation amongst these constructs.

\subsection{Hypothesis Development}

\subsubsection{Perceived Usefulness}

Davis (1989) defined perceived usefulness as - the degree to which a person believes that using a particular system would enhance his or her job performancell (Ibid, p.320). Previous studies have shown that perceived usefulness is an important predecessor to the intention to adopt and use a technology (Davis et al., 1989; Venkatesh, 1999, 2000; Venkatesh \& Davis, 2000). Potential adopters evaluate the consequences of their adoption activities based on the enduring desirability of usefulness obtained from the particular innovation (Chau, 1996; Venkatesh \& Davis, 2000). In addition, perceived usefulness is also known as performance expectancy (Venkatesh, 2003; Morris, 2003; Davis, 2003), this was based on the expectancy theory that mocks-up the function of belief in decision making (Porter and Lawler, 1968; Robey, 1979; Vroom, 1964). To explain that, an innovation is perceived to be of high effectiveness when a particular adopter believes that there is a direct relationship between use, on one hand, and performance, productivity, effectiveness and satisfaction, on the other ( $\mathrm{Lu}$ andYu, 2003). Although many mobile services are leisure related, services such as new, stock changes or banking can also stimulate how a user performs a task. In addition, characteristics that are inherent to mobile services, such as their personalized and ubiquitous nature, their portability, and their context awareness potential are likely to contribute to perceived usefulness of mobile services in ways that have not seen beforell (Rao and Troshani, 2007).

Aderonke and Charles (2010) mentioned that - people tend to use an application to the extent they believe it will aid their performancell. Amin et al., (2008) stated that perceived usefulness is strongly correlated with productivity. It suggests that using computer in the workplace would improve job performance, increase user's productivity, enhance job effectiveness and be valuable in the job. Cheong and Park (2005) found that there exists a positive causality between perceived usefulness and online purchase intentions. Laurn and Lin (2005) also stated that perceived usefulness has significant effect in the development of initial readiness to use mobile banking. These studies prove the significant effect of perceived usefulness in individual reactions to information technology. Hence, it is quite expected that the reason why people use mobile banking is because they find it useful. On these bases, the following hypothesis is proposed

H1: Perceived usefulness will have a positive effect on the behavioral intention to use mobile banking.

\subsubsection{Perceived Ease of Use}

Perceived ease of use refers to the degree to which a person believes that using a particular system would be effortless (Davis, 1989). In the mobile setting, perceived ease of use corresponds to the degree to which individuals relate freedom of difficulty with the use of mobile technology and services in daily usage (Knutsen et al., 2005).Some mobile devices could be complex or tedious to use, for instance Taylor and To dd (1995) mentioned that there are facts in the media that says using certain services on a mobile phone can be tiresome, especially when browsing internet-like interfaces on mobile devices. Fang et al., (2005) discovered that the nature of an innovation or a task or any service related to it may persuade its perceived ease of use. For instance, perceived ease of use affects the intended use of innovation only when it provides intrinsic motivation, but not when it provides extrinsic rewards to its users (Gefen and Straub, 2000). Several previous studies have shown that there is a positive relationship between perceived ease of use and usage intention. Luarn and Lin (2005) stated that there is a positive causality between perceived ease of use and the usage intention. Guriting and Ndubisi (2006) mentioned that perceived ease of use had a significant positive effect of behavioral intention to use online banking in Bangladesh. Ramayah et al., (2003) found that perceived ease of use has a major impact in the development of initial willingness to use internet banking. Davis et al., (1989) stated that perceived ease of use is an ancestor of perceived usefulness. Perceived ease of use is assumed to act as a predictor of perceived usefulness. In addition, both perceived usefulness and perceived ease of use predict attitude towards using a system (Yan et al., 2009). A system which is more convenient to use will facilitate more system use and accomplishment of tasks, rather than systems that are hard to use (Venkatesh and Morris, 2000). The following hypothesis was proposed

$\mathrm{H} 2$ : Perceived ease of use will have a positive effect on the behavioral intention to use mobile banking

H3: Compatibility will have a positive effect on the behavioral intention to use mobile banking

H4: Self efficacy will have a positive effect on the behavioral intention to use mobile banking.

H5: Subjective norm will positively influence intention to use Mobile banking

H6: Perceived Security and Privacy will have a positive effect on the credibility of use of mobile banking.

H7: Perceived credibility will have a positive effect on the behavioral intention to use mobile banking

H8: Perceived risk will have a negative effect on behavioral intention to use mobile banking.

H9: User predisposition will have a positive effect on behavioral intention to use mobile banking

\subsubsection{Conceptual Framework}

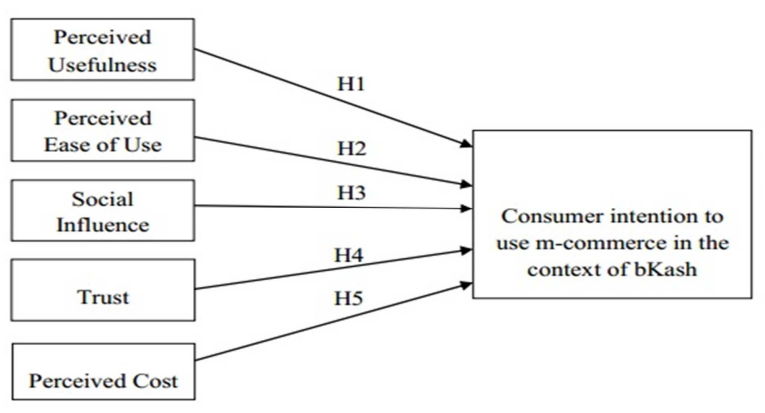

Figure 5. Conceptual Framework. 


\subsection{Research Approach}

In order to substantiate the hypothesis proposed on the key factors of mobile banking adoption in Bangladesh, it should be scientifically tested. In order for this to happen, data must be collected from the sample / population to be analyzed. There are several ways to collect information with the most prominent ways being via interview and questionnaires. This data is then originated using various mathematical techniques to find out information. As well as collecting data from the sample / population, a different way to collect information is through research and by studying previous work done on the topic to understand their findings and to achieve more knowledge about the topic. The sample / population are regularly determined early and are usually hurdled to the topic we are researching. For example, the topic is about Bangladesh, hence limit for the sample / population will be within the geographical area of Bangladesh. The reason for all this to ensure the data is accurate and not biased in any kind of way.

\subsection{Data Resources}

Primary data are the data gathered directly from firsthand experience. The defining characteristic of primary data is that data collected is unique and the research will stay unrevealed until the study is published. Primary data can be classified into two categories. Qualitative in nature is one of these primary data, which is usually text, based or quantitative in nature, which signifies the numerical values. Among the methods of collecting the primary data are via questionnaires, interviews, observations, group interviews, case-studies, diaries, critical incidents and portfolios. Secondary data is data that has already been collected for use in previous studies. Secondary data can also been divided into two based on their nature. These two natures are qualitative data which comprises of biographies, personal letters, documents, diaries, records, published material, computer database, and policy statements. The other nature is quantitative data; it would include market research, census, and economic documents, planning documents or specimens.

\subsection{Data Collection Method}

In this research, the data collection method was implemented through distributing questionnaires. The motive for using the questionnaires method for collecting data was because prior work which has been cited in this paper has all chosen this method. There are several advantages which make the questionnaire method most preferable. Amongst these advantages are it is cost effective, reduce bias (questionnaires are handed out randomly), and it has a large amount of correspondents. There are also other advantages of questionnaires such as its undisputed, respondents will have time to think about their response, no prior arrangements are needed when handing out questionnaires, and questionnaires can cover wide geographic location because it can be posted, faxed or e-mailed

The questionnaire method had been used for data collection for this study, the researcher distributed questionnaires among the bKash and DBBL users in different location of Dhaka and Jessore city. Researcher had a few reasons to choose this research method. These are as follows:

1. It allows large amounts of information to be obtained at a relatively low cost.

2. More accurate responses are expected to be obtained because interviewer bias is avoided.

\subsection{Questionnaire Design}

The questionnaire was designed, pre-tested and then administered to a random sample of mobile service subscribers. The questionnaire was designed to test these variables, Perceived Usefulness, Perceived Ease-of-use, Perceived Credibility, Perceived risk, Subjective Norm and User Predisposition and also to collect demographic information about the correspondents. Based on Luarn and Lin (2005), the questions for each construct shall be adapted from prior research. The first section was designed to collect demographic information of the respondents. There were 5 demographics which will give rough background information of the sample chosen. The questions covered gender, age, marital status, education attained, and also income level in the format of close-ended multiple-choice questions except for age. For perceived ease-of-use, the questions were adopted from Luarn and Lin (2005). On the other hand, for social influences, the questions were adopted from Luarn and Lin (2005), Lin and Wang (2005) and Wong and Hiew (2005). Additional questions regarding the other variables were also added. For all the constructs, a five- point Liker-type scale was used, ranking from 1 (strongly disagree) to 5 (strongly agree). By using the Liker scale, respondents were able to indicate their level of agreement or disagreement for each statement.

\subsection{Sampling Method}

After evaluating all possible methods of sampling, the most proper method for this research has been identified as convenience sampling method. This sampling method is anon-probability sampling technique where subjects are selected because of their convenient accessibility and proximity to the researcher. Convenience sampling generally assumes a homogenous population, and that one person is most likely like the other. Distribution of the questionnaires was done through personal administration. Written questionnaires reduce Interviewer bias because there is uniform question presentation.

\subsection{Sample Size/Population}

A total of 50 questionnaires were distributed randomly. The target respondents were those who are able to communicate in English, as the questionnaire will be constructed using English as the medium. Target respondents were people who own and use mobile communication devices, such as PDAs, hand phones or smart phones. The study will be covered within Dhaka, which will include 
students and various types of mobile users. The distribution method used for this study was paper based questionnaires

\subsection{Unit of Analysis}

For the unit of analysis, the focus group was individuals from the workforce and students within Dhaka, who are mobile service subscribers, aged between 20 - 49 years from various countries, background, religion, gender and age. The reason behind choosing this range is because based on the Hand Phone User Survey, the 20 - 49 age group has been illustrated as the highest users of mobile phones for 1-3 years of survey, from the year 2012-2014, the last survey being published was in 2014. Besides this, sources were students from various faculties, for instance, the unit analysis among the various users, agent and account holder. The motive behind this choice was that most of the students in Daffodil International University own mobile phone and have easy access to the internet and also Wi-Fi around the campus and at home. The reason why the questionnaires were targeted at individuals and not corporations is because corporations are usually bound to their personal corporate culture and changes are usually decided by the management.

\subsection{Data Analysis Techniques}

For the demographic section, Descriptive statistics was implemented to describe the basic features of the data in the study. Descriptive statistics present simple summaries about the sample and the measures. As for the constructs, inferential statistics was used. Inferential statistics are used in order to make judgments of the probability whether an observed difference between groups is a dependable one or one that might have happened by chance in this study. Multiple regression analysis has been chosen to test the hypotheses for the purpose of this study. The reason behind choosing multiple regression analysis is because it is basically applied to analyze relationships between a single dependent variable and a number of Independent variables. To implements data analyses, Statistical Package for the Social Sciences (SSPS) was adopted. To ensure the accuracy of the data, the data will be entered twice and to be able to check for any inconsistencies.

\section{Data Analysis}

\subsection{Introduction}

The objective of this chapter is to confer the data analysis and findings of this research based on various tests that were conducted on questionnaire items. First, respondents profile is discussed which includes demo graphics as well as their mobile usage. Subsequently, mean analysis for each variable is discussed using the means and standard deviations of items in each variable. This chapter also discusses Reliability tests and whether the results are reliable or not. Cranach's Alpha was used to conduct the reliability tests. Correlation of all variables was tested using the Spearman Rho's correlation coefficient, which was also used to test for hypotheses.

\subsection{Descriptive Analysis}

Of the 55 questionnaires that were distributed, 50 questionnaires were returned. However, 5 of them had to be rejected due to missing answers or incorrect filling-in. This means that there was a response rate of 90.90. Data was analyzed using the SPSS (Statistical Package for Social Science) software. Table-3 below shows a general demographic profile of the respondents and Table- 4 shows technical profile of respondents.

Table 3. Demography profile of respondents.

\begin{tabular}{|c|c|c|c|c|}
\hline & & Frequency & Percentage & Cumulative Percentage \\
\hline \multirow[t]{3}{*}{ Gender } & Male & 42 & 84 & 84 \\
\hline & Female & 8 & 16 & 100 \\
\hline & Total & 50 & 100 & \\
\hline \multirow[t]{4}{*}{ Age Group } & 15-20years & 5 & 10 & 10 \\
\hline & 21-25years & 22 & 44 & 54 \\
\hline & 26-30years & 15 & 30 & 84 \\
\hline & 31-aboveyears & 8 & 16 & 100 \\
\hline Nationality & Bangladeshi & 50 & 100 & \\
\hline \multirow[t]{3}{*}{ Marital Status } & Single & 36 & 72 & 72 \\
\hline & Married & 14 & 28 & 100 \\
\hline & Total & 50 & 100 & \\
\hline
\end{tabular}

Table 4. Respondents profile of Understanding m-banking.

\begin{tabular}{lllll}
\hline & & Frequency & Percentage & Cumulative Percentage \\
\hline Familiarity with mobile banking & Yes & 37 & 74 & 74 \\
& No & 5 & 10 & 84 \\
& Not that much & 8 & 16 & 100 \\
& Total & 50 & 50 & 36 \\
& Yes & 18 & 36 & 60 \\
\hline
\end{tabular}




\begin{tabular}{lllll}
\hline & & Frequency & Percentage & Cumulative Percentage \\
\hline & Once before & 10 & 20 & 80 \\
& A few times & 7 & 14 & 94 \\
& Intending to use in future & 3 & 6 & 100 \\
& Total & 50 & 100 & 26 \\
Used Mobile device & <1Years & 13 & 26 & 70 \\
& 1-lessthan3years & 22 & 44 & 90 \\
& 3-lessthan5years & 10 & 20 & 100 \\
5ormoreyears & 5 & 10 & \\
Satisfaction from mobile & Total & & 100 & 88 \\
application & Yes & 44 & 88 & 100 \\
& No & 6 & 12 & 70 \\
Use of Mobile banking & Total & 50 & 100 & 90 \\
& Very likely & 35 & 70 & 94 \\
& Somewhat likely & 10 & 20 & 100 \\
\hline
\end{tabular}

Most of the respondents are already familiar with mobile banking with $74 \%$. Results also have shown that $24 \%$ have never used mobile banking before, which could be because the banks they are dealing with doesn't provide this service or didn't properly advertise it to its customers. Majority of respondents are satisfied with their mobile application with a contribution of $88 \%$. Respondents that have used mobile banking before have contributed to a $36 \%$ which is considered below average. When the respondents were asked whether they intend to use mobile banking, 20\% mentioned that somewhat they're likely to use mobile banking.

Compares between bkash and DBBL mobile bank account type and others information in Bangladesh mobile banking system. (Until 10-12-2013)

Table 5. Account Holder of m-banking.

\begin{tabular}{lll}
\hline & Bkash & DBBL \\
\hline Account Holder & 7000000 & 1800000 \\
Male & $65 \%$ & $70 \%$ \\
Female & $35 \%$ & $30 \%$ \\
Student & $30 \%$ & $40 \%$ \\
Businessman & $20 \%$ & $15 \%$ \\
Service Holder & $40 \%$ & $35 \%$ \\
Farmers & $5 \%$ & $3 \%$ \\
Others & $5 \%$ & $7 \%$ \\
Active Client & $80 \%$ & $70 \%$ \\
Moderate & $15 \%$ & $10 \%$ \\
Low & $5 \%$ & $20 \%$ \\
\hline
\end{tabular}

\subsubsection{Mobile Bank Account Holder}

Account holder of bkash 7000000 above and DBBL 1800000 above (until 10-12-2013) Mobile banking account holder in Bangladesh.

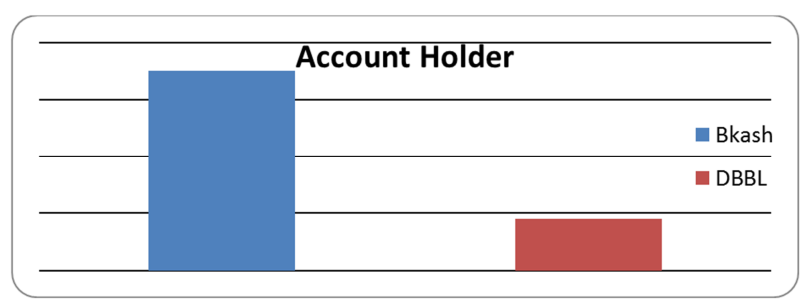

Figure 6. Account Holder Comparison.

\subsubsection{Gender of Survey Result}

Into the total no of account holder $35 \%$ of female and $65 \%$ male bkash and $30 \%$ of female and $70 \%$ male in DBBl mobile bank.

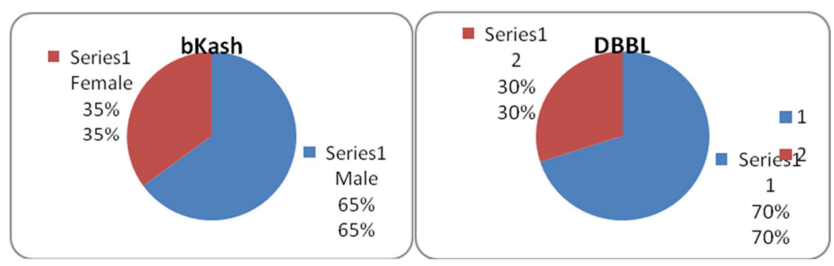

Figure 7. GenderSurveyResult.

\subsubsection{Respondents of Account Holder Occupation in M-bank}

In the respondent of mobile banking account holder most of them $40 \%$ student of DBBL and $30 \%$ of bkash bank limited and another of service holder and businessman and other categories.

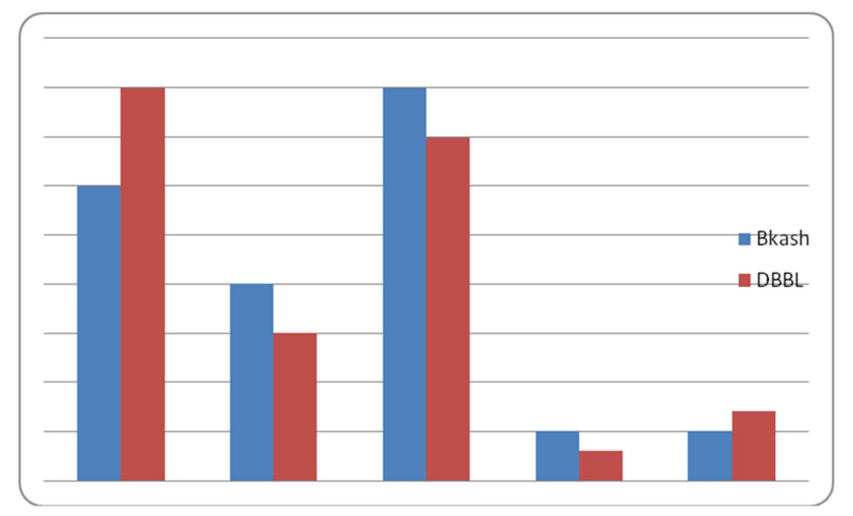

Figure 8. Account Holder Occupation.

\subsubsection{Respondents of Account Activity}

Responds survey among the mobile banking user which are most active client, moderate or lower activity. 


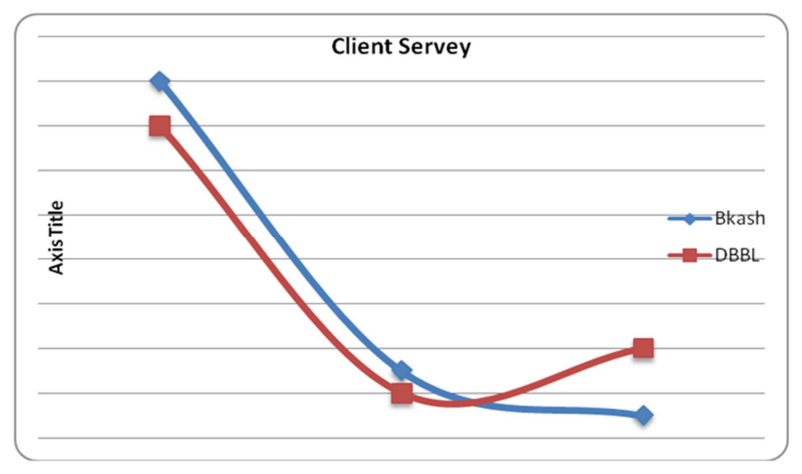

Figure 9. Account Holder Activities.

\subsection{Agents of M-banking Bangladesh}

There are various agents of mobile bank according to the division wise DBBL and bKash Mobile banking.

Table 6. Division wise Agent of Bangladesh.

\begin{tabular}{lll}
\hline Division/Agents & DBBL & bKash \\
\hline Dhaka & 24355 & 23763 \\
Chittagong & 10203 & 13392 \\
Sylhet & 3820 & 2959 \\
Barisal & 3668 & 4022 \\
Rangpur & 7242 & 6918 \\
Khulna & 6062 & 6723 \\
Rajhsahi & 6898 & 7213 \\
\hline
\end{tabular}

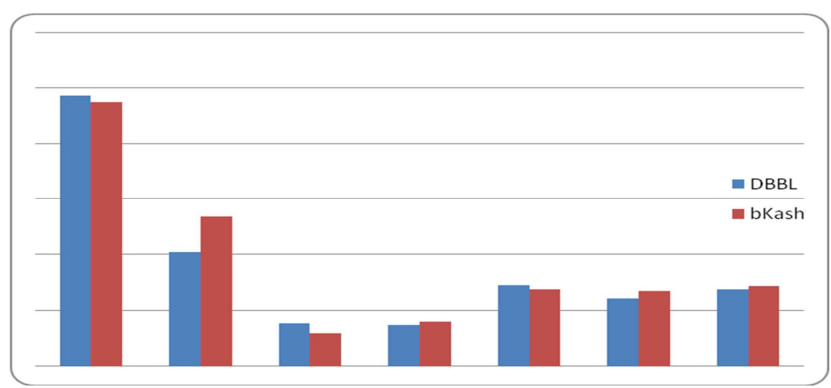

Figure 10. Agent of Mobile Bank in Bangladesh.

\subsection{Agents survey of M-bank in Bangladesh}

There are 20 agent was surveyed among various mobile banking agent in Dhaka. They have some question about mobile banking service and benefits. Show table 7

Table 7. Frequency of Agent and percentage.

\begin{tabular}{llll}
\hline & & Frequency & Percentage \\
\hline Network Quality for service & Good & 11 & 55 \\
& Moderate & 7 & 35 \\
& Bad & 2 & 10 \\
& Total & 20 & 100 \\
Transfer sms service & Smooth & 7 & 35 \\
& Medium & 10 & 50 \\
& Not & 3 & 15 \\
Deposit to be an agent & Total & 20 & 100 \\
& Yes & 0 & 0 \\
Satisfaction from mobile & No & 20 & 100 \\
application & Total & 20 & 100 \\
& Yes & 17 & 85 \\
& No & 3 & 15 \\
Any problems as an agent & Total & 50 & 100 \\
& Sometime & 6 & 30 \\
& Frequently & 1 & 5 \\
& Not & 13 & 65 \\
& Total & 20 & 100 \\
\hline
\end{tabular}

Table 8. Summary of Transaction.

\begin{tabular}{|c|c|c|c|c|c|c|c|c|c|c|}
\hline \multirow{2}{*}{$\begin{array}{l}\text { Transaction } \\
\text { Type }\end{array}$} & & \multicolumn{3}{|l|}{ Cash In } & \multicolumn{3}{|c|}{ Cash Out (Agent) } & \multicolumn{3}{|c|}{ Fund Transfer } \\
\hline & & Sub-Type & DBBL & IBBL & bKash & DBBL & IBBL & bKash & DBBL & IBBL \\
\hline Account per & Minimum & 50 & $\mathrm{~N} / \mathrm{M}$ & 50 & 50 & $\mathrm{~N} / \mathrm{M}$ & 50 & 10 & $\mathrm{~N} / \mathrm{M}$ & 10 \\
\hline Transaction & Maximum & 25000 & 25000 & 25000 & 25000 & 25000 & 25000 & 10,000 & 10000 & 10000 \\
\hline Daily Limit & Frequency & 5 & 5 & 5 & 3 & 3 & 3 & 20 & $\mathrm{~N} / \mathrm{M}$ & $\mathrm{N} / \mathrm{M}$ \\
\hline (Maximum) & Amount & 25000 & 25000 & 25000 & 25000 & 25000 & 25000 & 10000 & 10000 & 10000 \\
\hline Monthly Limit & Frequency & 20 & 20 & 20 & 10 & 10 & 10 & 70 & $\mathrm{~N} / \mathrm{M}$ & N/M \\
\hline (Maximum) & Amount & 150000 & $\mathrm{~N} / \mathrm{M}$ & 150000 & 150000 & $\mathrm{~N} / \mathrm{M}$ & 150000 & 25000 & 25000 & 25000 \\
\hline
\end{tabular}

Table 9. Limitation of Transaction services.

\begin{tabular}{|c|c|c|c|c|c|c|}
\hline \multirow{2}{*}{ Transaction Type } & \multicolumn{2}{|c|}{ Maximum Number of Transactions } & \multicolumn{2}{|c|}{ Amount Per Transaction } & \multicolumn{2}{|c|}{ Maximum Amount } \\
\hline & Per Day & Per Month & Minimum(Tk) & Maximum(Tk) & Per Day(Tk) & Per Month(Tk) \\
\hline Cash In & 5 & 20 & 50 & 25,000 & 25,000 & 150,000 \\
\hline Send Money & 20 & 70 & 10 & 10,000 & 10,000 & 25,000 \\
\hline Buy Airtime & 50 & 1500 & 10 & 1,000 & 10,000 & 100,000 \\
\hline Payment & No Limit & No Limit & 1 & No Limit & No Limit & No Limit \\
\hline Cash Out from Agent & 3 & 10 & 50 & 25,000 & 25,000 & 150,000 \\
\hline Cash Out from ATM & 3 & 10 & 2,000 & 20,000 & 25,000 & 150,000 \\
\hline International Remittance & 5 & 20 & 50 & 150,000 & 150,000 & 150,000 \\
\hline
\end{tabular}

Note: A bKash Account holder can keep a maximum amount of Tk.150, 000 in his/her bKash Account at any moment. 
4.5. No of Agents in Bangladesh to Serve Rural and Urban Clients: 64000 Above (10.12.2013)

Division

Dhaka

Agents

Chittagong

23763

Khulna

13392

Shylet

2959

Barisal

4022

Rajshahi

Rangpur

6918

\subsection{Relation with Core Banking System}

There is no Relationship between BRAC bank (Core Banking) and mobile banking service

\subsection{Operation Procedure}

Cash out process bKash From Brac Bank ATM bKash ATM Cash Out Service Activate
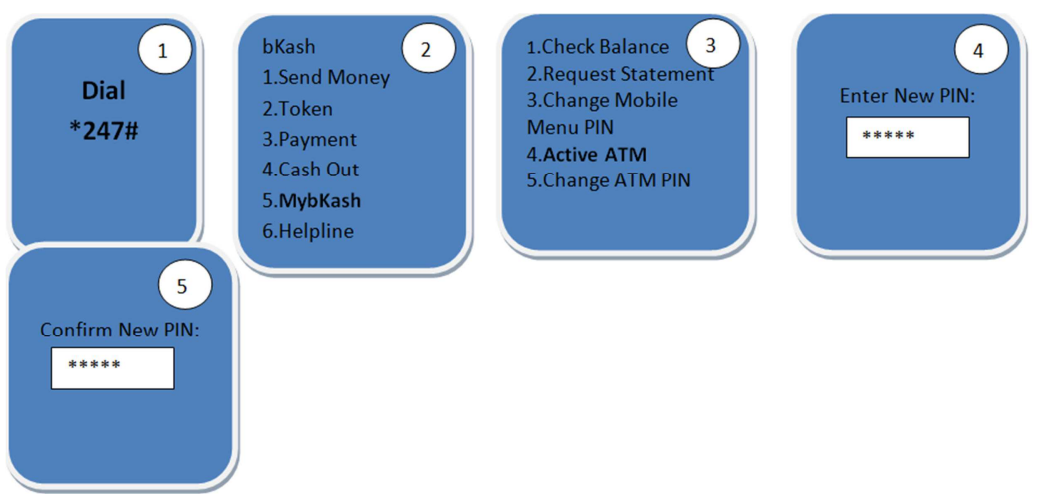

This Activation can be done by at first time. bKash ATM Pin can be changed anytime from bkash mobile menu. To Change bkash ATM pin go to mobile option "My bKash" and change pin number.

Cash Out From ATM

Cash out From bkash enable Brac Bank ATM Booth-

5. Confirm new pin. This bKash ATM Cash out pin

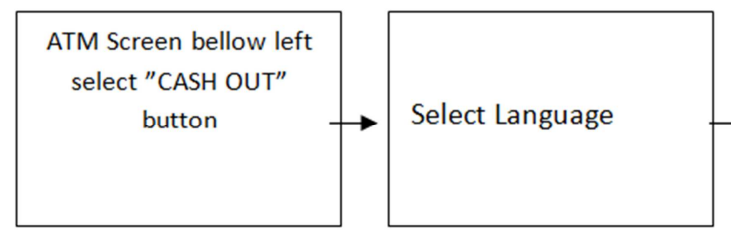

"bKash Account

Number" that means

Your mobile number

and confirm Account
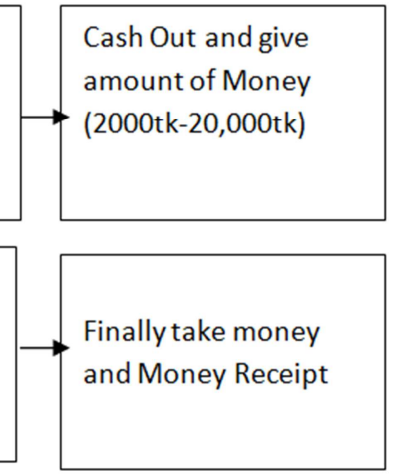

Low: $(20 \%)$

4. No of Agents in Bangladesh to serve rural and urban clients: $($ Total $=62248)$

$\begin{array}{ll}\text { Division } & \text { Agents } \\ \text { Dhaka } & 24355 \\ \text { Chittagong } & 10203 \\ \text { Sylhet } & 3820 \\ \text { Barisal } & 3668 \\ \text { Rangpur } & 7242 \\ \text { Khulna } & 6062 \\ \text { Rajhsahi } & 6898\end{array}$

5. Relation with core banking system:

At Present there is no relation but they are working to relationship between core banking and mobile banking operation. As soon as possible it will be work for account 
transfer and other banking related work

6. Operation Procedure:

What is my mobile account number?

Your Mobile account number is your mobile number with an additional check digit for example

If your mobile number is 01233445666 and check digit is

3 then your account number will be

012334456683

Where to cash-in (cash deposit)?

Customer can cash-in (deposit at any authorized agent of DBBL or DBBL Branch.

How does it work?

Customer hands over cash to Agent

Agent inflates the transaction, from his/her mobile

Agent gets prompt menu and $\mathrm{n}$ reply agent enters customer's mobile account number (including check digit) and amount

Agent enters his/her PIN

System credits customer's account for the same amount

Agent issues a receipt to the customer

System sends a SMS to the customer's mobile

For security reason customer needs o check the sending number of SMS at the amount

SMS will be sent from 16216 or 01190016216 if the amount of money is not correct or the SMS send from different number then it would not be considered as correct.

Where to cash-out (cash withdrawal)?

Customer can cash-out (withdraw) at any authorized agent point of DBBl or DBBL Branch

How does it work?

Customer asks the Agent or withdrawal of an amount from his or her mobile account

Agent initiates the transaction from his/her mobile

Agent gets prompt menu and in replay agent enters customer's mobile account number (Including check digit) and amount to withdraw

DBBL system sends prompt menu to the customer's mobile (or by IVR Call "You are going to withdraw Tk. $\mathrm{XXXX}$ from your mobile account with DBBL if you want to continue, please enter your 4-digit pin

Customer enters his/her PIN

System debited customers account and sends an SMS to the customers mobile

Agent hands over money to the customer

How will you send foreign remittance?

From the Nominated Exchange Houses of DBBL:

You can send remittance from any nominated Exchange

Houses of Dutch-Bangla Bank located

all over the word The remitted money would be transferred to the beneficiary's mobile account number within 24 hours

Understanding of Mobile Banking

Are you familiar with Mobile Banking services?
$\square$ Yes
$\square$ No
$\square$ Not that much

and the beneficiary will immodestly receive SMS about the deposit to avail the service just provide the flowing information at the exchange house:

Amount

Beneficiary's Name Bank Name (Dutch-Bangla Bank) and Mobile Account number

\section{Conclusion}

Basically the research was of descriptive in nature. Qualitative data are analyzed critically using judgment. Several statistical and analytical methods and tools were used for analyzing the gathered data from the survey. Column chart has been used as graphical tools to show the analysis of data. The package used in the study was: Microsoft Word, Microsoft Excel and survey about mobile banking.55\% feel interest to use mobile banking but most people do not want to give suggestion to other to use it. As it is a new method of banking people haven't $100 \%$ faith on it. So, people don't want to take any risk by giving suggestion to use it. $68 \%$ respondents say they do not want to give suggestion and $32 \%$ respondents say they want to give suggestion to use mobile banking.

Mobile banking is real time on-line banking, available anytime, anywhere throughout the country, it is convenient, affordable and secure, it is much more effective in developing savings habits, it will make access to banking and advanced payment transactions at affordable cost, it is much safer, speedy and safeguard against fraudulent transactions. All of the characteristics of mobile banking make life easier. But $43 \%$ respondents feel it will not make life easier as it may not be trust worthy, but $57 \%$ respondents feel the facility which mobile banking give will make life easi

\section{Annexure}

M-Bank Data Collection:

PART I (Annexure-1)

----Account Holder Survey----

Please tick the appropriate answer that is applicable to you Personal information

1. Gender

$\square$ Male $\quad \square$ Female

2. Age group

$\square$ 15-20 $\square 21-25 \square 26-30 \square 31$ and Above

3. Nationality

$\square$ Bangladeshi $\square$ Others

4. Marital Status

$\square$ Single $\quad \square$ Married 


\begin{tabular}{ll}
\hline Are you familiar with Mobile Banking services? & Have you used Mobile-banking services before? \\
\hline $\begin{array}{l}\text { How many years have you used mobile devices (such as cell phones and } \\
\text { PDAs) do you have? }\end{array}$ & $\begin{array}{l}\text { Are you satisfied with your banking institution's } \\
\text { Mobile application? }\end{array}$ \\
\hline$\square<1$ year & $\square$ Yes \\
$\square 1$-less than 3years & $\square$ No \\
$\square 3-$ less than 5years & \\
$\square 5$ or more years & \\
\hline
\end{tabular}

Mobile bank study:

\begin{tabular}{ll}
\hline Account holder gender? & Which Mobile banking are you like? \\
\hline$\square$ Male & $\square$ DBBL \\
$\square$ Female & $\square$ Bkash \\
Occupation of Account holder? & $\square$ Others \\
\hline$\square$ Student & Are you used mobile banking most frequently or types of active? \\
$\square$ Business Man & \\
$\square$ Service & $\square$ Active \\
$\square$ Farmers & $\square$ Moderate \\
$\square$ Others & $\square$ Low \\
\hline
\end{tabular}

\section{PART II(Annexure-2)}

----Bank Agent Survey----

\begin{tabular}{|c|c|c|c|c|c|c|c|}
\hline \multirow{2}{*}{\multicolumn{8}{|c|}{ Mobile Banking Agent }} \\
\hline & & & & & & & \\
\hline \multicolumn{2}{|c|}{ Sr. Question } & \multicolumn{3}{|c|}{ DBBL Mobile Bank } & \multicolumn{3}{|c|}{ bKash (BRAC Bank) } \\
\hline 1 & Network Quality for service & Good & Moderate & $\mathrm{Bad}$ & Good & Moderate & $\mathrm{Bad}$ \\
\hline 2 & Transfer Sms Service & Smooth & Medium & Not & Smooth & Medium & Not \\
\hline 3 & Number Of Clients Cash In/Payment(Average/day) & & & & & & \\
\hline \multirow{3}{*}{$\begin{array}{l}4 \\
5\end{array}$} & Deposit to be An Agent & How Much? & & & How Much? & & \\
\hline & Facilities As a Agent & & & & & & \\
\hline & Have any Problems As Agent? & $\begin{array}{l}\text { Yes } \\
\text { Comments. }\end{array}$ & No & & $\begin{array}{l}\text { Yes } \\
\text { Comments. }\end{array}$ & No & \\
\hline
\end{tabular}

\section{References}

[1] www.google.com.[Accessed on May.1, 2014].

[2] www.answer.com.[Accessed on Dec.12, 2013].

[3] www.bkash.com. [Accessed on Feb. 23, 2014].

[4] www.dbbl.com.bd. [Accessed on Feb.15, 2014].

[5] http://www.scribd.com/doc/. [Accessed on April 1, 2014].

[6] http://www.dutchbanglabank.com/electronic_banking/mobile_ banking.html.[Accessed April 1, 2014].

[7] BRAC Bank mobile bank news. [Accessed on Mar. 10, 2014].

[8] http://en.wikipedia.org/wiki/Mobile_banking. [Accessed on Mar 13, 2014].

[9] Mobile Financial Services in Bangladesh: An Overview of Market Development- Bangladesh Bank, July 2012

[10] S. M. S. Ahmed, S. J. Rayhan, M. A. Islam, and S. Mahjabin, "Problems and prospects of mobile banking in Bangladesh", Journal of Information Engineering and Applications, pp: Vol 1, no.6, pp.16-34, 2011.

[11] H. Bauer, M. Hammer schmidt, and T. Falk, "Measuring the quality of e-banking portals," International Journal of Bank Marketing, vol. 23, pp. 153-175, 2005.

[12] S. Barnes and B. Corbitt, "Mobile banking: Concept and potential," International Journal of Mobile Communications, vol. 1, pp. 273-288, 2003

[13] Rotimi, Oludele, and Bamidele, "SMS Banking Services: A $21^{\text {st }}$ century innovation in banking technology," Journal of Issues in Informing Science and Information Technology, vol. 4, pp. 227-234, 2007

[14] W. Poon, "Users' adoption of e-banking services: The Malaysian perspective," Journal of Business and Industrial Marketing, vol. 23, pp. 59-69, 2008.

[15] Brown, I., Cajee, Z., Davies, D., \& Stroebel, S. (2003). Cell phone banking: Predictors of adoption in South Africa--an exploratory study. International Journal of Information Management, 23(5), 381-394.

[16] Mobile Banking in Developing Countries: Secure Framework for Delivery ofSMS-banking Services, by Abunyang Emmanuel, Radboud University Nijmegen

[17] Niina Mallat, Matti Rossi, and Virpi Kristiina Tuunainen (2004), Mobile Banking Services Communications of the ACM, 47, 5 pp 42-46

[18] GSM technical specification (1997), Digital cellular telecommunications system (Phase 2+); General description of a GSM Public Land Mobile Network (PLMN), http://www.etsi.org.

[19] Jonathan Knudsen (2002), MIDP Application Security: design Concerns and Cryptography, Sun Developer network; $\mathrm{http}: / /$ developers.sun.com/techtopics 
[20] William Stallings (2003), Network Security Essentials, Pearson Education, Inc. Upper Saddle river, New Jersey USA.

[21] Jonathan Knudsen (2002), MIDP Application Security: design Concerns and Cryptography, Sun Developer network. http://developers.sun.com/techtopics

[22] CGAP 2006. 'Mobile Phone Banking and Low-Income Customers Evidence from South Africa' retrieved from: http://www.globalproblems-globalsolutions- Retrieved on 12 July, 2012

[23] $\mathrm{ABC}$ knowledge center leading: the chance of business research in Bangladesh

[24] Amin, H., Hamid, M. R. A., Lada, S., \& Anis, Z. (2008). The adoption of mobile banking in Malaysia: The case of Bank Islam Malaysia Berhad (BIMB).International Journal of Business and Society, 9, 43-53.

[25] Amin, H., Muhammad, M. Z., Hamid, M. R. A., \& Lada, S. (2006). Explaining intention to use SMS banking among Bank Islam Malaysia Berhad (BIMB) customers: Is gender a good indicator? Proceeding of IBBC, 2, 92-101

[26] Baraghani, S., N. (2007) Factors Influencing the Adoption of Internet Banking. Master Thesis. Tarbiat Modares University of Engineering Department of Industrial Engineering.

[27] Cheong, J. H., \& Park, M. C. (2005). Mobile internet acceptance in Korea. Internet Research, 15(2), 125-140.

[28] Chiu, Y. B., Lin, C. P., \& Tang, L. L. (2005). Gender differs: Assessing a model of online purchase intentions in e-tail service. International Journal of Service Industry Management, 16(5), 416-435.

[29] Compeau, D. R., \& Higgins, C. A. (1995). Computer selfefficacy: Development of a measure and initial test. MIS Quarterly, 19(2), 189-211.
[30] Guriting, P., \& Ndubisi, N. O. (2006). Borneo online banking: Evaluating customer perceptions and behavioural intention. Management Research News, 29(1/2), 6-15. Jayawardhena, C., \& Foley, P. (1998).

[31] Overcoming Constraints on Electronic Commerce - Internet Payment Systems. Journal of General Management, 24(2), 1935.

[32] Kohli, K. (2004). SMS in banking. Paladion Knowledge Series, Issue January 2004. [On-line]. Available: http://www.paladion.net/papers/KSeries Secure SMS Banking.pdf

[33] http://www.scribd.com/doc/103647559/2.[Accessed on Jan. 10, 2014].

[34] Lin, H. H. (2010), An Empirical Investigation of Mobile Banking Adoption: The Effect of Innovation Attributes and Knowledge-Based Trust. International Journal of Information Management.

[35] How croft, B., Hamilton, R., \& Hewer, P. (2002). Consumer attitude and the usage and adoption of home-based banking in the United Kingdom. International Journal of Bank Marketing, 20(3), 111- 121

[36] Wang, Y. S., Wang, Y. M., Lin, H. H., \& Tang, T. I. (2003). Determinants of user acceptance of internet banking: An empirical study. International Journal of Service Industry Management, 14(5), 501-519.

[37] http://www.bb.org.bd/fnansys. [Accessed on April 23, 2014]. 